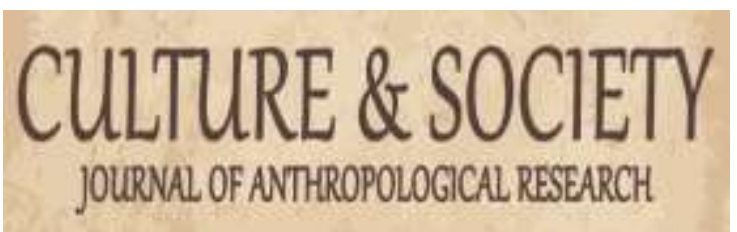

Culture \& Society: Journal of Anthropological Research

VOL. 3 NO. 1 SEPTEMBER 2021

http://culture.ppj.unp.ac.id

Email: culture@ppj.unp.ac.id

ISSN: 2686-343X (E-ISSN) 2686-3421 (P-ISSN)

DOI: https://doi.org/10.24036/csjar.v3i1.90

\title{
Peran Ganda Perempuan Buruh Tani Karet
}

\author{
Eki Parmana ${ }^{1}$, Erda Fitriani ${ }^{2}$ \\ ${ }^{1,2}$ Universitas Negeri Padang \\ Email: ekiparmana11@gmail.com, fitriani_cim@fis.unp.ac.id
}

\begin{abstract}
Abstrak
Penelitian ini dilatarbelakangi oleh perempuan yang bekerja sebagai buruh tani dan bekerja di rumah. Penelitian ini bertujuan untuk mendeskripsikan peran ganda perempuan buruh tani karet dalam memenuhi kebutuhan keluarga di kampung Sawah Liek, Kenagarian Lagan Hilir Kabupaten Pesisir Selatan. Pemilihan informan dilakukan secara purposive sampling. Teknik pengumpulan data yang digunakan dalam penelitian ini adalah observasi partisipasi, wawancara mendalam (indepth interview), dan studi dokumen. Data dianalisis dengan teknik analisis interaktif Miles dan Huberman dengan cara reduksi data, penyajian data dan penarikan kesimpulan. Hasil penelitian menunjukkan bahwa peran ganda perempuan buruh tani karet bekerja di dua sektor yaitu sektor domestik dan sektor publik. Penyebab perempuan bekerja di dua sektor adalah untuk menambah pendapatan keluarga guna memenuhi kebutuhan hidup dan dipengaruhi oleh pendidikan yang rendah dan tidak memiliki keterampilan yang memadai untuk bekerja di bidang lain.
\end{abstract}

Kata Kunci: Buruh Tani Karet, Peran ganda, Perempuan, Teori AGL

\section{Abstract}

This research is motivated by women who work as farm laborers and work at home. This study aims to describe the dual role of women rubber farm workers in meeting the needs of families in Sawah Liek village, Kenagarian Lagan Hilir, Pesisir Selatan Regency. The selection of informants was done by purposive sampling. Data collection techniques that will be used in this study are observation, in-depth interviews, and document studies. The data were analyzed by Miles and Huberman's interactive analysis technique by means of data reduction, data presentation and drawing conclusions. The results showed that the dual role of female rubber farm laborers worked in two sectors, namely the domestic sector and the public sector. The reason why women work in two sectors is to increase family income to meet the needs of life and is influenced by low education and lack of adequate skills to work in other fields. The impact of dual roles for the family is the difficulty in carrying out their domestic tasks, the less optimal time they have to share the roles they carry out, and the fatigue of activities in their work professionally. Keywords: AGIL Theory, Dual Role, Rubber Farmers, Women

\section{\begin{tabular}{l|l|l} 
Received: August 14, 2021 & Revised: September 26, 2021 & Published: September 29, 2021
\end{tabular}}

Culture \& Society: Journal of Anthropological Research Vol. 3, No. 1, Th. 2021 


\section{Pendahuluan}

Pembangunan pertanian sebagai realisasi dari kebijakan pemerintah telah tersebar di berbagai daerah dengan potensi yang berbeda, karena potensi yang berbeda itu maka pelaksanaan pembangunan pertanian akan didasarkan pada ketersedian sumberdaya alam yang dominan di daerah tersebut dan daya dukung lainnya. Salah satu Sektor pertanian Sumatera Barat yang merupakan sektor unggulan adalah perkebunan karet dan kelapa sawit. Tanaman karet dan kelapa sawit ini adalah tanaman tahunan yang dapat tumbuh sampai umur 30 tahun (Badan Pusat Statistik Kabupaten Pesisir Selatan, 2018).

Mata pencaharian masyarakat di kabupaten Pesisir Selatan di dominasi dengan berkebun karet. Disamping itu, mengulas masalah ketenagakerjaan di negara kita merupakan masalah yang tiada henti-hentinya (Hanum et al., 2018). Kurangnya lapangan pekerjaan, tingginya angka pengangguran, kemiskinan, dan sebagainya merupakan masalah sosial yang kian hari semakin parah. Hal ini tidak hanya terjadi pada kaum laki-laki sebagai pemikul tanggung jawab dalam mencari nafkah. Istripun ikut memikul tanggung jawab tersebut meskipun perannya sebagai ibu rumah tangga sudah cukup kompleks.

Dalam kedudukan yang vital ini perempuan memiliki berbagai peranan, tergantung dalam kaitan mana kita melihatnya; yang sudah merupakan pendapat umum berkaitan dengan pelaksanaan peranannya sebagai ratu rumah tangga itu, pertama-tama ialah berkaitan dengan tata laksana kerumahtanggaan, tatalaksana makanan dan tatalaksana busana atau pakaian. Peranannya ini, yang kadang dianggap kurang berarti, sebenarnya tidak sesederhana dugaan orang. Ketiga jenis tatalaksana tersebut kini bahkan telah merupakan bidang studi yang cukup luas dan kompleks (Badan Pusat Statistik Indonesia, 2018).

Masalah yang muncul bagi petani karet saat turunya harga karet dunia adalah menurunnya tingkat kesejahteraan masyarakat petani karet, imbas yang dihasilkan dari penurunan itu berdampak sekali pada petani karet, bahkan, ketika karet benar-benar tidak menjadi sektor yang diperhatikan pemerintah lagi, maka pendapatan keluarga petani karet juga mengalami penurunan.

Kabupaten Pesisir Selatan terdiri dari lima belas kecamatan yang setiap tahunnya produksi karet di setiap kecamatan ada yang mengalami peningkatan, ada juga yang mengalami penurunan dan juga perbedaan produksi setiap kecamatan.

Tabel 1. Produksi Tanaman Karet di Kabupaten Pesisir Selatan

\begin{tabular}{llll} 
& \multirow{2}{*}{ Kecamatan } & \multicolumn{3}{c}{ Produksi Tanaman Karet (ton) } \\
\cline { 2 - 4 } & $\mathbf{2 0 1 6}$ & $\mathbf{2 0 1 5}$ & $\mathbf{2 0 1 4}$ \\
\hline Lunang Silaut & 500 & 606 & 1.114 \\
\hline Silaut & 679 & 107 & 1.114 \\
\hline Lunang & 1.131 & 1.339 & 1.674 \\
\hline Basa Ampek Balai Tapan & 1.306 & 783 & 1.249 \\
\hline Pancung Soal & 181 & 192 & 146 \\
\hline Air pura & 70 & 136 & 516 \\
\hline Linggo Sari Baganti & 1.201 & 1.448 & 1.107 \\
\hline Ranah Pesisir & 123 & 149 & 309 \\
\hline Lengayang & 622 & 751 & 547 \\
\hline Sutera & 314 & 372 & 284 \\
\hline Batang Kapas & 1.725 & 2.040 & 1.560 \\
\hline IV Jurai & 358 & 435 & 332 \\
\hline Bayang & 1.473 & 1.779 & 1.361 \\
\hline IV Nagari Bayang Utara & 256 & 311 & 240 \\
\hline Koto XI Tarusan & 171 & 187 & 147 \\
\hline Kabupaten Pesisir Selatan & $\mathbf{1 0 . 1 1 0}$ & $\mathbf{1 0 . 6 4 1}$ & $\mathbf{1 1 . 7 3 3}$ \\
\hline
\end{tabular}


Masalah ekonomi dalam keluarga buruh tani karet adalah persoalan yang ikut menyertakan kehidupan petani karet sebagai dampak dari penurunan harga karet. Biasanya, perempuan dalam keluarga buruh tani karet hanya sekedar membantu suami di kebun karet. Semenjak harga karet turun, maka perempuan pada keluarga buruh tani karet bekerja di perkebunan, sehingga mengakibatkan perempuan buruh tani karet memiliki peran yang sama dengan suaminya untuk mencari nafkah. Keterlibatan perempuan dalam kegiatan ekonomi merupakan fenomena penting dalam era globalisasi, salah satu daerah yang peneliti temukan mengenai perempuan yang bekerja sebagai buruh tani karet di kampung Sawah Liek Kenagarian Lagan Hilir Punggasan Kabupaten Pesisir Selatan, di nagari ini banyak perempuan bekerja sebagai buruh tani karet tujuan mereka bekerja adalah untuk memenuhi kebutuhan keluarga (Hanum et al., 2018).

Biaya rumah tangga yaitu untuk pemenuhan kebutuhan primer, pangan dan sandang. Sedangkan untuk kebutuhan sekunder adalah untuk kebutuhan pendidikan anak, kebutuhan sosial berupa berbagai iuran atau sumbangan. Banyaknya biaya rumah tangga mempengaruhi pendapatan yang telah dihasilkan. Sehingga jika pengeluaran cukup banyak maka hal ini membuat ibu-ibu berusaha mencari tambahan untuk memenuhi kebutuhan hidup dalam rumah tangga (Suparman, 2017). Hal ini senada dengan pernyataan Susilowati (2020) yang mengatakan bahwa perempuan Indonesia harusnya tampil sebagai penunjang dalam upaya ketahanan ekonomi keluarga melalui berbagai aktivitasnya baik di ranah domestik maupun publik.

Penelitian yang relevan dengan penelitian ini dilakukan oleh Patricia Suryani, Jurusan Sosiologi, Fakultas Sosial dan Imu Politik, Universitas Sebelas Maret Surakarta yang berjudul "Kontruksi Sosial Atas Buruh Tani Istri di Masyarakat Desa (Studi kasus pada masyarakat desa Karang Sari Kecamatan Ngawi, Kabupaten Ngawi Propinsi Jawa Timur)". Penelitian ini menggunakan teori konstruksi sosial atas realitas yang dikemukakan oleh Peter L. Berger. Penelitian ini merupakan studi kasus yang membahas konstruksi sosial atas buruh tani perempuan pada masyarakat Desa Karangasri, Kecamatan Ngawi, Kabupaten Ngawi. Teknik pengumpulan data digunakan wawancara, observasi, dan dokumentasi. Hasil penelitian ditemukan bahwa buruh tani perempuan merupakan perempuan-perempuan sebagai tenaga kerja yang dikarenakan beberapa hal menyebabkan mereka bekerja sebagai buruh tani, dengan kata lain, buruh tani perempuan ialah pencari nafkah kedua dalam keluarga.

Buruh tani perempuan bekerja bukan atas dasar kewajiban mencari nafkah utama melainkan hanya untuk memenuhi kebutuhan ekonomi subsisten. Konstruksi sosial terbangun atas realitas yang dialami di masyarakat. Konstruksi sosial atas buruh tani perempuan, didasari atas beberapa faktor pembentuk, diantaranya faktor ekonomi (penghasilan, pengeluaran, kemampuan menabung), sosial budaya (interaksi, budaya yang berkembang), pendidikan (pendidikan yang ditempuh buruh tani perempuan tersebut serta pendidikan anak-anaknya) (Suryani, 2012).

Terdapat persamaan antara penelitian yang dilakukan dengan studi ini, yakni membahas tentang peran perempuan buruh tani dalam bekerja untuk mencari nafkah dalam mencukupi kebutuhan keluarga. Namun terdapat perbedaan, dalam penelitian yang dilakukan oleh Patricia Suryani hanya terfokus pada konstruksi sosial atas buruh tani perempuan serta faktor-faktor yang mendasari pembentukan konstruksi sosial tersebut. Hal yang belum diungkapkan pada penelitian tersebut ialah mengenai bagaimana keberlanjutan keberadaan buruh tani perempuan di pedesaan. Sedangkan pada penelitian yang dilakukan lebih terfokus untuk melihat peran dari perempuan sebagai buruh tani karet, penyebab yang mendasari profesi perempuan buruh tani karet serta melihat dampak keberlanjutan atas profesi terebut apakah mencukupi kebutuhan keluarganya dan pengaruhnya dalam menjalankan tugas domestiknya.

Fenomena ini menarik dikaji lebih dalam karena merupakan suatu hal yang baru di kehidupan masyarakat. Untuk menganalisis penelitian peran ganda perempuan buruh tani karet yang bekerja dalam menjalankan peran ganda mereka dapat dikaji dengan menggunakan teori

Culture \& Society: Journal of Anthropological Research Vol. 3, No. 1, Th. 2021 
Agil oleh Talcott Parsons. Menurut teori fungsionalis ini masyarakat adalah "suatu sistem sosial yang terdiri atas bagian-bagian atau elemen yang saling berkaitan dan saling menyatu dalam kesimbangan. Perubahan yang terjadi satu bagian akan membawa perubahan pula terhadap bagian lain (Ritzer, 2010).

Masyarakat dilihat sebagai sebuah sistem dimana seluruh struktur sosialnya terintegrasi menjadi satu, masing-masing memiliki fungsi yang berbeda-beda tapi saling berkaitan dan menciptakan konsensus dan keteraturan sosial serta keseluruhan elemen akan saling beradaptasi baik terhadap perubahan internal dan eksternal dari masyarakat (Ritzer, 2010). Talcott Parsons terkenal dengan empat imperatif fungsional bagi sistem "tindakan" yaitu skema AGIL. AGIL, fungsi adalah suatu gugusan aktivitas yang diarahkan untuk memenuhi satu atau beberapa kebutuhan sistem. Parsons menyakini bahwa perkembangan masyarakat berkaitan erat dengan perkembangan keempat unsur subsistem utama yaitu kultural (pendidikan), kehakiman (integrasi), pemerintahan (pencapaian tujuan) dan ekonomi (adaptasi) (Suyanto, 2011). Menggunakan definisi ini, Parsons percaya bahwa ada empat imperatif fungsional yang diperlukan atau menjadi ciri seluruh sistem yaitu adaptasi, goal attainment, integrasi dan latency atau pemeliharaan pola. Secara bersama-sama, keempat imperatif fungsional disebut dengan skema AGIL. Agar bertahan hidup maka sistem harus menjalankan keempat fungsi tersebut (Ritzer, 2010).

Berdasarkan observasi yang dilakukan diperoleh informasi bahwa dengan adanya penurunan harga karet yang ada di Kampung Sawah liek kenagarian Lagan Hilir Punggasan Kabupaten Pesisir Selatan mengakibatkan banyaknya perempuan berprofesi sebagai buruh tani karet. Bedasarkan wawancara yang dilakukan dengan Kepala Kampung Sawah Liek, semenjak harga karet turun drastis perempuan buruh tani di Kampung Sawah Liek ikut serta membantu meningkatkan kebutuhan keluarga mereka, karena pendapatan suami tidak cukup untuk memenuhi kebutuhan keluarga. Berdasarkan latar belakang tersebut, penulis tertarik untuk mengangkat penelitian skripsi ini dengan judul: "Peran Ganda Perempuan Buruh Tani Karet" Studi Kasus; Kampung Sawah Liek, Kenagarian Lagan Hilir Punggasan Kabupaten Pesisir Selatan".

\section{Metode Penelitian}

Penelitian mengenai peran ganda perempuan buruh tani karet dalam memenuhi kebutuhan keluarga dilakukan di kampung Sawah Liek Kenagarian Lagan Hilir Punggasan Kabupaten Pesisir Selatan. Pemilihan lokasi tersebut dilatarbelakangi oleh beberapa hal diantaranya yaitu selain kaum laki-laki yang bekerja sebagai buruh tani ternyata berdasarkan observasi juga ditemukan sebagian besar kaum perempuan juga bekerja sebagai buruh tani.

Penelitian mengenai perempuan buruh tani karet dalam memenuhi kebutuhan keluarga dilakukan dengan menggunakan pendekatan penelitian kualitatif. Pendekatan kualitatif dapat diartikan sebagai metode yang berlandaskan pada filsafat post-positivisme, digunakan untuk meneliti kondisi objek yang alamiah, dimana peneliti sebagai instrument kunci, teknik pengumpulan data dilakukan secara triangulasi (gabungan), analisis data bersifat induktif /kualitatif, dan hasil penelitian kualitatif lebih menekankan makna dari pada generalisasi (Sugiyono, 2012). Metode penelitian kualitatif dilakukan secara intensif, peneliti ikut berpartisipasi selama di lapangan, mencatat secara hati-hati apa yang terjadi, melakukan analisis replektif terhadap berbagai dokumen yang ditemukan di lapangan, dan membuat laporan penelitian secara mendetail. Pendekatan kualitatif dipandang mampu mendefinisikan peran ganda buruh tani perempuan di kampung Sawah Liek Kenagarian Lagan Hilir Punggasan Kabupaten Pesisir Selatan. Tipe penelitian yang digunakan yaitu tipe penelitian studi kasus instrisik, yaitu studi kasus yang dalam penelitian ini diharapkan mampu memberikan gambaran secara menyeluruh mengenai peran ganda buruh tani perempuan di kampung Sawah Liek Kenagarian Lagan Hilir Punggasan Kabupaten Pesisir Selatan. 
Informan dalam penelitian ini dilakukan secara purposive sampling, yaitu informan penelitian yang telah ada dan ditentukan kriterianya sesuai dengan permasalahan penelitian. Kriteria informan yang dimaksud dalam penelitian ini adalah informan sudah tercakup namanya dari data yang telah peneliti dapatkan.

Teknik purposive sampling dalam melihat dari permasalahan penelitian sudah jelas informan yang peneliti libatkan, adapun informan pada penelitian ini yaitu buruh tani perempuan yang bekerja di kampung Sawah Liek Kenagarian Lagan Hilir Punggasan Kabupaten Pesisir Selatan yang berjumlah 17 orang. Teknik pengumpulan data yang digunakan dalam penelitian ini adalah observasi, wawancara mendalam (indepth interview), dan studi dokumen. Penelitian ini yang diamati adalah tentang peran ganda perempuan buruh tani di kampung Sawah Liek Kenagarian Lagan Hilir Punggasan Kabupaten Pesisir Selatan.

Observasi merupakan teknik pengumpulan data dengan melakukan pengamatan dan pencatatan secara sistematik terhadap fenomena dan gejala yang ada pada objek penelitian (Ritzer, 2010). Observasi dilakukan dengan mengumpulkan data melalui kegiatan peneliti mengamati secara langsung ke lapangan pada masyarakat yang akan diteliti yaitu bagaimana peran ganda perempuan buruh tani di kampung Sawah Liek Kenagarian Lagan Hilir Punggasan Kabupaten Pesisir Selatan. Bentuk peran ganda yang dimaksud adalah sebagai ibu dalam merawat anak dan suami, serta sebagai istri dalam mendidik anak dan ekonomi.

Wawancara mendalam (indepth interview) dimaksudkan untuk memperoleh keterangan, pendirian, pendapat secara lisan dari seseorang dengan berbicara langsung (face to face) dengan orang tersebut, dengan demikian, wawancara berbeda dengan ngobrol, bercakap-cakap, dan beramah tamah (Suyanto, 2011). Kegiatan penelitian dilakukan dengan cara turun langsung ke lapangan dengan cara mengamati langsung objek penelitian yang merupakan perempuan buruh tani karet yang bekerja sebagai buruh tani karet. Kemudian dilakukan wawancara dan melakukan observasi tentang kegiatan-kegiatan dan aktivitas mereka yang berkaitan dengan penelitian ini.

Teknik wawancara yang akan dilakukan dalam penelitian ini adalah wawancara mendalam (indepth interview). Teknik ini dilakukan agar peneliti memperoleh data yang mendalam terhadap hal yang diteliti mengenai peran ganda perempuan buruh tani di Kampung Sawah Liek Kenagarian Lagan Hilir Punggasan Kabupaten Pesisir Selatan. Aktivitas wawancara penulis lakukan kepada masing-masing informan, yang dijadikan sebagai subjek penelitian ini dengan menggunakan kisi-kisi yang sudah dibuat dan disiapkan sebelumnya, agar wawancara bisa lebih terarah dan menajdi lebih baik. Hasil penelitian dari observasi dan wawancara akan lebih dapat dipercaya jika didukung oleh studi dokumen (Sugiyono, 2012). Adapun media yang peneliti gunakan adalah handphone. Untuk memperoleh data yang valid, maka dalam penelitian ini dilakukan dengan triangulasi data. Teknik triangulasi ada beberapa macam antara lain adalah triangulasi sumber, metode dan teori (Ghony \& Almanshur, 2016).

Analisis data diperoleh dilapangan dianalisis secara terus menerus dengan menggunakan model Interactive Model of Analisys (Miles \& Huberman, 1992).

\section{Reduksi Data}

Data yang telah direduksi dapat memberikan gambaran lebih tajam tentang hasil wawancara dan memudahkan untuk mencari jika sewaktu-waktu diperlukan. Dalam proses pengumpulan data dan pengelompokkan data peneliti akan menggunakan kode-kode dan poinpoin tertentu supaya memperoleh gambaran yang jelas peran ganda perempuan buruh tani karet di kampung Sawah Liek Kenagarian Lagan Hilir Punggasan Kabupaten Pesisir Selatan.

\section{Penyajian Data}

Penyajian data dimaksudkan agar memudahkan peneliti untuk melihat gambaran secara keseluruhan atau bagian-bagian tertentu dari penelitian, dengan kata lain pengorganisasian data yang telah utuh dimana peneliti mengelompokkan data berdasarkan fokus masalah yaitu mengenai peran ganda perempuan buruh tani karet dikampung Sawah Liek Kenagarian Lagan Hilir Punggasan Kabupaten Pesisir Selatan. 


\section{Penarikan Kesimpulan}

Penarikan kesimpulan dilakukan secara terus menerus sepanjang proses penelitian berlangsung, sejak awal memasuki lapangan atau selama proses pengumpulan data. Penelitian dilakukan dengan mencari makna dari data yang dikumpulkan yaitu dengan mencari pola dan tema yang dituangkan dalam kesimpulan mengenai mengenai peran ganda perempuan buruh tani karet di Kampung Sawah Liek Kenagarian Lagan Hilir Punggasan Kabupaten Pesisir Selatan.

\section{Hasil dan Pembahasaan}

Peran ganda merupakan dua peran yang dijalankan oleh seorang saja dalam menjalankan suatu tugas yang memang sudah menjadi hal yang dikerjakannya (bekerja) dan juga salah satu peran itu telah menjadi kodrat yang memang telah melekat dari dahulu pada diri dan tanggung jawabnya (ibu rumah tangga) di dalam sebuah keluarga.

Peran ganda perempuan adalah peran perempuan di suatu pihak keluarga sebagai pribadi yang mandiri, ibu rumah tangga, mengasuh anak-anak dan sebagai istri serta dipihak lain sebagai anggota masyarakat, sebagai pekerja dan sebagai warga negara yang dilaksanakan secara seimbang. Perempuan dianggap melakukan peran ganda apabila ia bertanggung jawab terhadap tugas-tugas domestik sekaligus juga bertanggung jawab atas tugas publik bekerja di luar rumah, bahkan sebagai pencari nafkah utama (Christian, 2019).

\section{Peran Perempuan di Sektor Domestik}

Berdasarkan observasi dan hasil wawancara peneliti memperoleh informasi dari beberapa informan mengenai kegiatan apa saja yang dilakukan sebagai perempuan dalam sektor domestik yaitu sama halnya dengan pekerjaan yang biasa dilakukan seperti mengurus rumah, memasak, mencuci pakaian, menemani anak belajar, mempersiapkan kebutuhan sekolah anak dan lain sebagainya. Hal ini dapat dilihat dari salah satu penuturan seorang informan mengenai kegiatan yang dilakukannya di rumah sebelum berangkat bekerja, Bu Ati (53 tahun):

“...sebelum pergi kerja ibu bangun jam 4 pagi, kemudian menyiapkan bekal untuk keluarga, setelah selesai ibu berangkat ke kebun, setelah pulang kerja dari kebun ibu membersihkan rumah dan kembali menyiapkan makan untuk makan malam.."

Perempuan buruh tani karet seakan tidak mengenal waktu, mereka tetap menjalankan tugas domestiknya sebagai seorang ibu di dalam keluarga sebagaimana layaknya di samping kesibukannya menjalankan pekerjaan sebagai buruh tani karet meskipun dengan kondisi yang melelahkan demi memenuhi kebutuhan keluarga.

Hal ini juga terjadi pada perempuan buruh tani harian di kebun sawit. Menurut Melis (2018), pengaturan atau pengelolaan kerumahtanggaan merupakan tugas utama para wanita, khususnya para ibu rumah tangga. Kegiatan ini seolah-olah tidak mengenal waktu dalam pelaksanaannya. Tugas ini antara lain berkaitan dengan penyiapan makan dan minum bagi seluruh anggota keluarga seperti mengasuh mendidik, menjaga dan mengarahkan anak-anak terutama bagi yang belum dewasa; mengurus, membersihkan dan membereskan rumah termasuk perabot rumah tangga dan menjaga kebersihan dan kerapian pakaian seluruh anggota keluarga. Melihat tugas kerumah tanggaan yang harus dipikul oleh seorang ibu rumah tangga tidak mempunyai waktu lagi untuk kegiatan yang lain, begitu bangun tidur mereka telah dihadapkan dengan setumpuk tugas yang harus dilakukan.

\section{Peran Perempuan di Sektor Publik}

Demi memenuhi kebutuhan hidup sehari-hari seorang perempuan buruh tani karet bekerja di kebun karet sebagai buruh tani karet, dan sebagai buruh tani harian di sawah serta sebagai 
pembantu di rumah orang yang mengadakan acara pernikahan. Sesuai dengan pendapat Prasetio (2020) yang menjelaskan bahwa tujuan perempuan petani karet yang bekerja sebagai petani hanya untuk membantu perekonomian keluarganya, akibat dari kebutuhan yang bertambah, gaya hidup, tagihan yang harus dibayar, bahkan utang piutang yang menumpuk. Bekerja sebagai buruh tani karet membuat perempuan harus mampu mengelola waktu agar bekerja dengan waktu yang optimal tanpa mengesampingkan peranannya sebagai ibu rumah tangga dalam menjalankan tugas domestiknya di rumah. Hal ini sejalan dengan pendapat Malihatin dan Wahyuningsih (2015) yang menjelaskan bahwa istripun ikut memikul tanggung jawab tersebut meskipun perannya sebagai ibu rumah tangga sudah cukup kompleks. Kecuali itu pandangan orang tentang seputar peranan laki- laki dan ibu rumah tangga memberikan peluang bagi kaum ibu rumah tangga untuk bekerja di luar rumah mencari nafkah, walaupun secara tradisional orang beranggapan bahwa mencari nafkah atau menafkahi keluarga adalah tanggung jawab kaum adam.

Berdasarkan observasi dan wawancara yang dilakukan dapat diperoleh informasi bahwa perempuan buruh tani karet sebelum berangkat perlu menyiapkan peralatan terlebih dahulu untuk dibawa ke kebun seperti alat penyadap karet dan parang serta menyiapkan bekal untuk dimakan ketika beristirahat. Kemudian mereka perlu membeli pupuk urea yang nantinya digunakan untuk mengeraskan getah yang telah disadap.

Perempuan buruh tani karet biasanya bekerja 6 hari dalam seminggu mulai dari hari sabtu hingga kamis, yang dimana karet tersebut akan dijual lagi ke toke (pengumpul). Alokasi waktu yang diperlukan perempuan buruh tani karet dalam bekerja tergantung pada jumlah karet yang akan disadap. Setelah karet yang disadap dirasa cukup, perempuan buruh tani karet beristirahat sejenak sembari memulihkan tenaga dengan makan siang yang telah dibawa sebelum berangkat. Selanjutnya mereka kembali bekerja, memberi pupuk pada getah yang telah di sadap agar getah tersebut cepat mengering sehingga apabila diguyur hujan getah tersebut tidak tumpah.

Perempuan buruh tani karet menjual karet setiap hari kamis atau seminggu sekali. Perempuan buruh tani karet membawa karetnya dengan menggunakan gerobak kira-kira dengan berat $30 \mathrm{~kg}$ dengan kondisi jalan yang menurun dan mendaki. Hal ini membutuhkan waktu 5 menit untuk sampai ke tempat pengumpul/toke. Hasil penjualan karet yang diperoleh selama seminggu kurang lebih sekitar Rp 300.000-400.000.

Pendapatan buruh tani karet dirasakan cukup mampu untuk membantu memenuhi kebutuhan keluarga. Hal ini sesuai dengan hasil penelitian yang diperoleh oleh Basriwijaya (2019) yang menjelaskan bahwa pendapatan wanita tani penyadap karet di Desa Pasir Utama pertahunnya adalah Rp. 10.977.559, pendapatan yang diperoleh oleh wanita tani penyadap karet tersebut menurut mereka dirasakan sudah cukup. Kontribusi pendapatan wanita tani terhadap pendapatan suami yaitu sebesar 31,98 \% terhadap peningkatan pendapatan keluarga.

Berdasarkan hal tersebut, dapat disimpulkan bahwa dengan adanya peran ganda perempuan buruh tani karet setidaknya mampu mencukupi kebutuhan keluarga. Hal ini sejalan dengan hasil penelitian yang dilakukan oleh Jalil dan Yurisna (2020) yaitu peran ganda perempuan mampu mengantisipasi keadaan keluarganya dalam bidan keuangan dan kebutuhan sehari-hari. Walaupun harus berpikir ekstra dan harus memikirkan pendistribusian keuangan dalam keluarganya mengingat pendapatan yang relative rendah.

\section{Analisis Peran Ganda Perempuan menurut Teori Gender}

Peneliti menggunakan teori AGIL oleh Talcott Parsons dalam mengkaji hasil penelitian ini. Menurut teori fungsionalis ini masyarakat adalah "suatu sistem sosial yang terdiri atas bagian-bagian atau elemen yang saling berkaitan dan saling menyatu dalam kesimbangan. Perubahan yang terjadi satu bagian akan membawa perubahan pula terhadap bagian lain (Ritzer, 2010). Dari hasil penelitian diatas peneliti menggunakan 3 imperatif fungsional dari Talcott Parsons dalam mengkaji hasil penelitian tersebut, yaitu :

Culture \& Society: Journal of Anthropological Research Vol. 3, No. 1, Th. 2021 


\section{A (Adaptasi)}

Sistem harus mengatasi kebutuhan situasional yang datang dari luar. Ia harus beradaptasi dengan lingkungan dan menyesuaikan lingkungan dengan kebutuhan-kebutuhannya. Adaptasi yang dilakukan perempuan menikah yang bekerja sebagai buruh tani karet disini yaitu dengan membagi waktu untuk mengerjakan pekerjaan domestik dan mengerjakan pekerjaan publik dengan tepat. Mereka harus memastikan bahwa peran ganda yang mereka lakukan benar-benar harus terlaksana dengan baik tanpa berbenturan.

\section{G (Goal/tujuan)}

Pencapaian tujuan, sistem harus mendefinisikan dan mencapai tujuan-tujuan utamannya. Tujuan perempuan berkeluarga yang bekerja sebagai buruh tani karet di kebun dalam menjalankan peran ganda yaitu, agar kedua peran tidak berbenturan dan dapat terselesaikan dengan baik. Dapat menyelesaikan semua pekerjaan sebagai ibu rumah tangga dengan baik dan dapat bekerja sebagai buruh dengan baik. Itulah tujuan dari buruh perempuan dalam menjalankan peran ganda agar dua peran yang dijalaninya tidak berantakan dan berjalan dengan baik.

\section{I (Integrasi/penyatuan)}

Integrasi, sistem harus mengatur hubungan bagian-bagian yang menjadi komponennya. Ia pun harus mengatur hubungan antar ketiga imperative fungsional tersebut $(A, G, L)$. Penyatuan yang dilakukan oleh ibu rumah tangga yang bekerja sebagai buruh tani untuk tetap menjaga kehidupan rumah tangganya dan tetap bekerja sebagai buruh tani di kebun. Seperti menanamkan nilai kerja sama dirumah, tolong-menolong untuk mengerjakan pekerjaan rumah, menanamkan nilai toleransi, nilai pengertian satu sama lain agar terciptanya suasana yang harmonis didalam rumah.

\section{L (Latency/pemeliharaan pola)}

Sistem harus melengkapi, memelihara dan memperbaharui motivasi individu dan polapola budaya yang menciptakan dan mempertahankan motivasi tersebut. Pola yang dilakukan oleh buruh perempuan yang bekerja sebagai buruh tani karet dalam menjalankan peran gandanya yaitu membagi waktu dengan baik dalam mengerjakan pekerjaan domestik dan bekerja dipublik. Walaupun harus bekerja sebagai buruh, waktu berinteraksi dengan anak tetap harus dilakukan karena keluarga adalah tempat belajar anak yang pertama dan paling dasar. Dalam mengatur keuangan keluarga pun seorang ibu sangat berperan terlebih lagi dalam kasus ini, buruh perempuan harus membagi-bagi pengeluaran dengan sangat baik agar semua kebutuhan tercukupi.

Tujuan dari perempuan bekerja sebagai buruh tani karet adalah untuk menambah pendapatan keluarga guna memenuhi kebutuhan sehari-hari. Biaya hidup yang semakin hari semakin meningkat membuat perempuan ikut bekerja, walaupun suami mereka juga bekerja tapi penghasilan yang didapatkan suaminya tidak cukup untuk memenuhi kebutuhan hidup keluarganya.

Hal ini sejalan dengan hasil penelitian yang dilakukan oleh Alfiati (2020) yang menjelaskan bahwa faktor penyebab perempuan berperan ganda adalah jumlah tanggungan keluarga yang banyak, memanfaatkan ilmu yang telah dimiliki, membantu suami memenuhi kebutuhan keluarga dan untuk mengisi waktu luang. Hal utama yang sangat terbantu ketika istri memutuskan untuk bekerja adalah tercukupinya kebutuhan keluarga dan meringankan beban suami dalam mencukupi kebutuhan keluarga. Hal ini juga sejalan dengan penelitian Sinadia (2017) yang menjelaskan bahwa pendapatan yang diperoleh perempuan dengan bekerja sebagai buruh sudah sangat membantu suami dalam memenuhi dan mencukupkan kebutuhan dalam rumah tangga setiap hari. Sehingga bila tanpa kontribusi dari perempuan, maka kebutuhan dalam keluarga belum dapat tercukupi. 
Dari penelitian yang telah dilakukan peneliti melihat, perkembangan zaman membawa perubahan cara berpikir. Dulu seorang perempuan yang bekerja adalah hal yang tabu, perempuan selalu identik dengan urusan rumah tangga dan mengurus anak. Tetapi pada saat sekarang ini, perempuan yang bekerja adalah hal yang lumrah dan sangat diterima dalam masyarakat. Perempuan dapat bekerja sesuai cita-cita mereka, mengembangkan karir, dan memperluas relasi. Dalam penelitian ini, banyak perempuan yang memilih bekerja karena tuntutan ekonomi mereka, biaya kebutuhan sehari-hari yang harus dicukupi dan biaya sekolah anak menjadi penyebab perempuan terjun ke sektor publik dan menjadi buruh pabrik. Hal ini juga didukung oleh suami dan anak mereka, pekerjaan rumah pun dapat terselesaikan dengan tolong menolong, karena pada prinsipnya, tak kerja tak makan.

\section{Kesimpulan}

Berdasarkan hasil penelitian yang telah peneliti lakukan di lapangan dalam mengkaji peran ganda perempuan buruh tani karet dalam memenuhi kebutuhan keluarga dapat disimpulkan bahwa penyebab perempuan buruh tani melakukan peran ganda adalah faktor intern yaitu pendapatan suami yang belum mencukupi kebutuhan hidup sehari hari, ditambah dengan pengeluaran dan jumlah tanggungan dalam keluarga, faktor ekstern yaitu lingkungan sekitar yang berupa lahan pertanian yang banyak membutuhkan tenaga buruh tani, pendidikan yang rendah serta memiliki keterampilan yang tidak memadai sehingga tidak ada peluang untuk kerja lainya. Bentuk peran ganda perempuan buruh tani karet yaitu sebagai Ibu, merawat anak dan suami, sebagai istri, mendidik anak dan ekonomi membantu suami mencari nafkah, untuk menambah pendapatan rumah tangga.

\section{Daftar Pustaka}

Alfiati, L. (2020). Peran Ganda Perempuan dalam Keharmonisan Rumah Tangga: Studi Kasus di Desa Ngabar Kecamatan Siman Kabupaten Ponorogo. Jurnal Studi Islam dan Sosial, 13(1).

Badan Pusat Statistik Kabupaten Pesisir Selatan. (2018). Kecamatan Linggo Sari Baganti Dalam Angka Tahun 2018. In Badan Pusat SIwatstik Kabupaten Pesisir Selatan, 53(9). https://doi.org/10.1017/CBO9781107415324.004

Badan Pusat Statistik Indonesia. (2018). Statistik Karet Indonesia. Journal of Petrology. https://doi.org/10.1017/CBO9781107415324.004

Basriwijaya, K.M.Z. (2019). Kontribusi Wanita Tani Penyadap Karet Terhadap Peningkatan Pendapatan Keluarga Di Desa Pasir Utama Kecamatan Rambah Hilir Kabupaten Rokan Hulu. Jurnal Peternakan Lingkungan Tropis, 2(1).

Christian, C. (2019). Peran Ganda Perempuan Pemulung Etnis Batak Di Tempat Pembuangan Akhir Muara Fajar Kecamatan Rumbai Pekanbaru. JOM FISIP, 6(1).

Ghony, D. M \& Fauzan, A. (2016). Metodologi Penelitian Kualitatif. Yogyakarta: Ar-Ruzz Media.

Hanum, I. M., Qurniati, R., \& Herwanti, S. (2018). Peran Wanita Pedesaan Hutan dalam Peningkatan Pendapatan Rumah Tangga. Jurnal Sylva Lestari, 6(3), 36-45. https://doi.org/10.23960/js13636-45

Jalil, Iwan Abdul dan Yurisna Tanjung. (2020). Peran Ganda Perempuan Pada Keluarga Masyarakat Petani di Desa Simpang Duhu Dolok Kabupaten Mandailing Natal. Jurnal Intervensi Sosial dan Pembangunan (JISP) Vol 1 No 1 Maret 2020, 58-70

Sinadia, J., Welson, M.W. \& Noortje M.B. (2017). Kontribusi Buruh Perempuan Terhadap Pendapatan Keluarga (Studi Kasus Tempat Pelelangan Ikan Di Tumumpa Kota Manado). Agri-SosioEkonomi Unsrat, ISSN 1907-4298, 13(1), 253 -260

Wahyuningsih, S. (2015). Kontribusi Buruh Wanita Penyadap Karet Terhadap Pendapatan Keluarga (Studi Kasus Di PTPN IX Kebun Balong/Beji-Kalitelo Afdelling Ngandong Kabupaten Jepara). Malihatin. 11(1), 12-24. 
Melis, M. (2018). Analisis Gender: Peran Ganda Istri Pekerja Buruh Harian di Perkebunan Sawit Untuk Memenuhi Kebutuhan Keluarga Dalam Perspektif Ekonomi Islam (Studi Deskriptif Pada Pt. London Sumatera, Trans Subur Muara Lakitan, Musi Rawas). An Nisa'a: Jurnal Kajian Gender dan Anak, 13(2).

Miles, B. \& Huberman, M. (1992). Analisis Data Kualitatif Buku Sumber Tentang Metode-metode Baru. Jakarta: UIP.

Ritzer, G. (2010). Sosiologi Ilmu Pengetahuan Berparadigma Ganda. Jakarta: PT. Raja Grafindo Persada.

Sugiyono, S. (2012). Metode Penelitian Kuantitatif, Kualitatif, dan R\&D. Bandung: Alfabeta, CV.

Suparman, S. (2017). Peran Ganda Istri Petani (Studi Kasus di Desa Perangian Kecamatan Baraka Kabupaten Enrekang). Edumaspul-Jurnal Pendidikan, 1(2), 104-114.

Suryani, P. (2012). Kontruksi Sosial Atas Buruh Tani Istri di Masyarakat Desa (Studi kasus pada Masyarakat Desa Karang Sari Kecamatan Ngawi, Kabupaten Ngawi Propinsi Jawa Timur). Skripsi. FISIP, Universitas Sebelas Maret, Surakarta.

Susilowati, I., \& Hakiem, F. N. (2020). Optimalisasi Peran Perempuan Sebagai Strategi Alternatif Kebijakan Publik Dalam Menekan Penyebaran Pandemi Covid-19. SALAM: Jurnal Sosial dan Budaya Syar-I, 7(8), 723-736. https://doi.org/10.15408/sjsbs. v7i8.16551

Suyanto, B. (2011). Metode Penelitian Sosial. Jakarta: Prenada Media Grup.

Prasetio, Y. (2020). Peran Ganda Perempuan Petani Di Desa Kelawat Kecamatan Sungai Lala Kabupaten Indragiri Hulu. JOM FISIP, 7(2). 